\title{
THE EFFECT OF CUSTOMER TRUST AND COMPANY IMAGE ON CUSTOMER SATISFACTION AND CUSTOMER LOYALTY IN INDONESIA CLASSIFICATION BUREAU IN SAMARINDA
}

\author{
Syariful Mahsyar', ${ }^{1}$ Suharno $^{2}$, Zainal Abidin ${ }^{3}$ \\ Faculty of Economics and Business, Mulawarman University \\ Email : syarifumashsyar@gmail.com, suharno@feb.unmul.ac.id, zainal.abidin@feb.unmul.ac.id
}

\begin{abstract}
This study aims to determine the effect of customer trust and company image on customer satisfaction and customer loyalty at the Indonesian Classification Bureau. The population in this study were customers of PT BKI with a total of 95 respondents. The method of data collection is done by giving a list of questions or questionnaires to respondents who are customers at PT BKI, where the questionnaire is distributed to these customers. This study uses a data analysis tool that is partial Least Square (PLS), then this study uses the analysis method of structural equation models or Path Analysis to determine the causal relationship between latent variables contained in structural equations. The tool used in data processing using the Smart PLS program. The results of this study indicate that 1) customer trust has a significant effect on customer satisfaction, 2) company image has a significant effect on customer satisfaction, 3) customer trust has a significant effect on customer loyalty, 4) company image has a significant effect on customer loyalty, 5) customer satisfaction has an significant effect to customer loyalty.
\end{abstract}

Keywords: $\quad$ Customer Trust, Company Image, Customer Satisfaction, Customer Loyalty

\section{Introduction}

As a developing country, Indonesia has become a potential market, where this phenomenon illustrates a condition of competition from today's increasingly fast business world. Facing increasingly competitive competition, companies are required to be able to create their own uniqueness in order to attract consumer attention and always pay attention to consumer needs and desires and try to meet consumer expectations by providing more satisfying services. Service quality has a close relationship with customer satisfaction and customer loyalty.

Indonesia is an archipelago consisting of islands separated by oceans. Therefore, a means of connecting (transportation) is needed to transport people and goods to the islands. Transportation is basically the movement of people and goods from one place to another. The transfer aims to achieve and increase benefits and efficiency. The transfer can take the form of using means or transportation by land, sea and air, although there are many means and routes of transportation but transportation by sea is still needed.

A key factor for a company's success in surviving is maintaining long-term relationships with customers. This is because, in addition to the costs of acquiring new customers being five times greater than the costs involved in satisfying and maintaining Kotler and Keller (2000: 58) 
International Journal of Economics, Business and Accounting Research (IJEBAR)

Peer Reviewed - International Journal

Vol-4, Issue-3, 2020 (IJEBAR)

E-ISSN: 2614-1280 P-ISSN 2622-4771

https://jurnal.stie-aas.ac.id/index.php/IJEBAR

customers, establishing good relationships with customers is the most effective way to increase customer satisfaction and loyalty. customer.

Building a trusting relationship takes time and process. Trust will develop gradually based on mutual adaptation, so that trust emerges from the accumulation of previous satisfying experiences, Gounaris (2003). Trust is a continuous process that is reinforced by positive evaluation of previous experiences. In addition to paying attention to the effect of customer trust, companies must also pay attention to the value of their own corporate image to increase customer satisfaction and customer loyalty.

Company image is defined as the overall impression on the customer's mind as a result of the accumulation of feelings, ideas, attitudes and experiences with the organization stored in memory which may turn into positive or negative meanings, which are taken to reconstruct the image and remember when the name of the organization is heard or thought of by someone. (Bravo et al., 2009) .

Ships are a form of sea transportation that functions to carry goods, passengers, mining materials, and others in all areas that have certain water areas. Since most of the $2 / 3$ of the earth's surface is water, ships have long been used by humans as a very important means of transportation for trade relations, spreading religion, searching for gold or spices, diplomatic relations, and others. Of course, ships that sail must meet certain requirements in order to be said to be fit for sailing, in Indonesia the agency that performs classification of ships is the Indonesian Classification Bureau (BKI).

The Indonesian Classification Bureau (BKI) is a State-Owned Enterprise (BUMN) in the form of a Limited Liability Company (PT Persero) which is engaged in the classification of ships operating in the maritime territory of the Republic of Indonesia. In its services, the company carries out research activities and publishes and applies technical standards by carrying out maritime design, construction and survey related activities. The Indonesian Classification Bureau (BKI), which is the 4th classification body in Asia after Japan, China and Korea, is the only national classification body tasked with classifying Indonesian-flagged commercial vessels and foreign-flagged vessels that regularly operate in waters. Indonesia.

Consumer trust is also very necessary, including the Indonesian Classification Bureau (BKI), consumer confidence is of course indispensable in the services performed so that consumers are expected to be satisfied with the Indonesian Classification Bureau (BKI) so that it will lead to a loyal attitude towards the company. The Indonesian Classification Bureau (BKI) is not the only body that performs ship classification, so BKI must also create a good corporate image in the eyes of consumers with the services provided in order to provide satisfaction to consumers who use services which will have a positive impact on company including the loyalty of these consumers.

In an effort to get customer satisfaction and customer loyalty, it is necessary to make efforts that can increase customer satisfaction which then customers will become loyal. One of the efforts that can be done is to increase consumer confidence. Halliburton and Poenaru (2010) reveal that trust is created through the bonds of rational and emotional relationships. Rational trust refers to the willingness of consumers to surrender to competent and reliable service providers, while emotional trust is a trust arising from consumers' feelings of a level of care and concern for service providers. Research conducted Hidayat \& Akhmad (2015) with the title "Effects of Service Quality, Customer Trust and Customer Religious Commitment on Customer Satisfaction and Loyalty of Islamic Banks in East Java " by using SEM analysis showed that the customer trusts a significant effect on customer satisfaction . Research conducted by Sarwar, Abbasi, \& Pervaiz (2012) entitled " The Effect of Customer Trust on Customer Loyalty and Customer Retention: A Moderating Role of Cause Related Marketing " reveals that customer trust has a significant effect on customer loyalty . 
International Journal of Economics, Business and Accounting Research (IJEBAR)

Peer Reviewed - International Journal

Vol-4, Issue-3, 2020 (IJEBAR)

E-ISSN: 2614-1280 P-ISSN 2622-4771

https://jurnal.stie-aas.ac.id/index.php/IJEBAR

Apart from consumer trust, corporate image is also important in increasing customer satisfaction and customer loyalty. Company image is defined as the overall impression on the customer's mind as a result of the accumulation of feelings, ideas, attitudes and experiences with the organization which are stored in memory which may turn into positive / negative meanings, which are taken to reconstruct the image and remember when the name of the organization is heard or thought of by someone ( Bravo et al ., 2009). Research conducted by Abd-el-salam \& Shawky (2013) entitled " The Impact Of Corporate Image And Reputation On Service Quality, Customer Satisfaction and Customer Loyalty: Testing The Mediating Role. Case Analysis in an International Service Company"reveals that company image has a significant effect on customer satisfaction. Setyono (2015) in his research entitled "The Effect of Islamic Marketing and Corporate Image on Customer Satisfaction and Customer Loyalty (Study on Customers of PT Bank Muamalat Indonesia Malang Branch Office) " using path analysis and the number of respondents as many as 138 , revealed that the company image has a significant effect on customer loyalty.

In this study the object used is PT Biro Klasifikasi Indonesia which is a company that runs a company in a B2B ( Business to Business ) manner, where business customers have their own characteristics and uniqueness, if B2C (Busnines to Customer) is the main focus of end users or users. end of a product but B2B customers are corporate customers. B2B operates in both market types both national and global levels. The most important factor in managing B2B relationships and success is how companies create sustainable relationships in order to build and create customer loyalty (Zimmerman \& Blythe, 2013), not just a transactional relationship between customers and suppliers, but marketing success, namely by establishing a harmonious relationship with customer. Several studies in the business to business area say that service quality generates customer loyalty (Doma, 2013).

This study aims to determine The Effect of Customer Trust and Company Image on Customer Satisfaction and Customer Loyalty In Indonesia Classification Bureau in Samarinda.

\section{Literature Review \\ Customer Satisfaction}

Generally, customer expectations are estimates or customer beliefs about what he will receive when he buys or consumes a product. Perceived performance is the customer's perception of what he receives after consuming the purchased product / service. Customer satisfaction can also be interpreted as a person's feeling of pleasure or disappointment with a product after he has compared the results / achievements of the product thought to the expected performance or product / service results. If the performance meets expectations, the customer will be satisfied. But if the performance exceeds customer expectations, then this means the customer is satisfied or very satisfied (Kotler and Keller, 2005: 70).

Zeithaml et al. ( 2003 ) states that satisfaction is the customer's evaluation of a product or service in terms of their ability to meet customer needs and wants. The word " satisfaction " comes from Latin, namely " satis" (meaning good enough, adequate) and "factio" (doing or making). So that satisfaction can be interpreted as 'an effort to fulfill something' or 'making something adequate' (Tjiptono and Chandra, 2005: 349).

Based on the definitions above, it can be concluded that satisfaction is the result of an assessment from the customer that the product or service has provided a level of enjoyment where this level of fulfillment can be happy or disappointed with a product or service. If this customer satisfaction occurs, it can be mutually beneficial to the product or service provider.

\section{Customer Loyalty}

Loyalty can also be seen as a firmly held commitment to consistently repurchase preferred products or services in the future (Sheng and Liu, 2010). Meanwhile, Tjiptono (2014: 
International Journal of Economics, Business and Accounting Research (IJEBAR)

Peer Reviewed - International Journal

Vol-4, Issue-3, 2020 (IJEBAR)

E-ISSN: 2614-1280 P-ISSN 2622-4771

https://jurnal.stie-aas.ac.id/index.php/IJEBAR

482) states that customer loyalty is a customer commitment to a brand, based on a very positive attitude and is reflected in consistent repeat purchases.

Customer loyalty ( customer loyalty) in the context of services marketing, Tjiptono (2014: 482) as a response are closely linked to a pledge or a promise to uphold the commitment that underlies the sustainability of relationships and are usually reflected in sustainable purchasing from providers of similar services on the basis of dedication and constraints pragmatic .

Kotler \& Keller ( 2009) defines that customer loyalty is a condition in which someone has a firm commitment to repurchasing a product or service .

According to Griffin (2010: 31) there are 3 attributes of loyalty, namely:

a. Makes regular repeat purchases, making purchases repeatedly within a certain period.

b. Purchase across product and service lines, loyal customers not only buy one kind of product but buyers of other product lines and services in the same business entity.

c. Other refers, recommend experiences about products and services to colleagues or other customers so as not to buy products and services from other business entities.

\section{Customer Trust}

Jones and Sasser (2009: 249) define trust as a positive result of what is expected, the results that a person receives based on the expectations of the performance of others. Trust will develop gradually based on mutual adaptation, so that trust arises from the accumulation of previous satisfying experiences (Gounaris, 2003).

Halliburton and Poenaru (2010) stated that trust is created through the bonds of rational and emotional relationships. Rational trust refers to the willingness of consumers to surrender to competent and reliable service providers, while emotional trust is trust arising from consumers' feelings of a level of care and concern for service providers.

Based on the definitions above, it can be concluded that trust as a positive result of one's experience is in accordance with expectations. Trust is formed gradually from previous experiences which can strengthen the bond between a person and the service provider.

\section{Company Image}

Company image is defined as the overall impression on the customer's mind as a result of the accumulation of feelings, ideas, attitudes and experiences with the organization which are stored in memory which may turn into positive / negative meanings, which are taken to reconstruct the image and remember when the name of the organization is heard or thought of by someone ( Bravo et al ., 2009) .

Company image is defined by Nguyen and Leblanc ( 2002: 228 ) as something that is associated with physical attributes and company behavior such as company name, architecture, products and services, and the impression of quality communicated by consumers who have used the product and service company.

Bravo et al. ( 2009) defines the corporate image as the result of a communication process where organizations create and disseminate specific messages that become the strategic goals of their mission, vision, goals and identity that reflect the core values they value.

Based on the definitions above, it can be concluded that the company's image is the result of one's feelings, attitudes, experiences with the company which refers to the overall products or services the company has used. (Bravo et al, 2009), Nguyen and Leblanc (2002: 228). 


\section{Hypothesis Development}

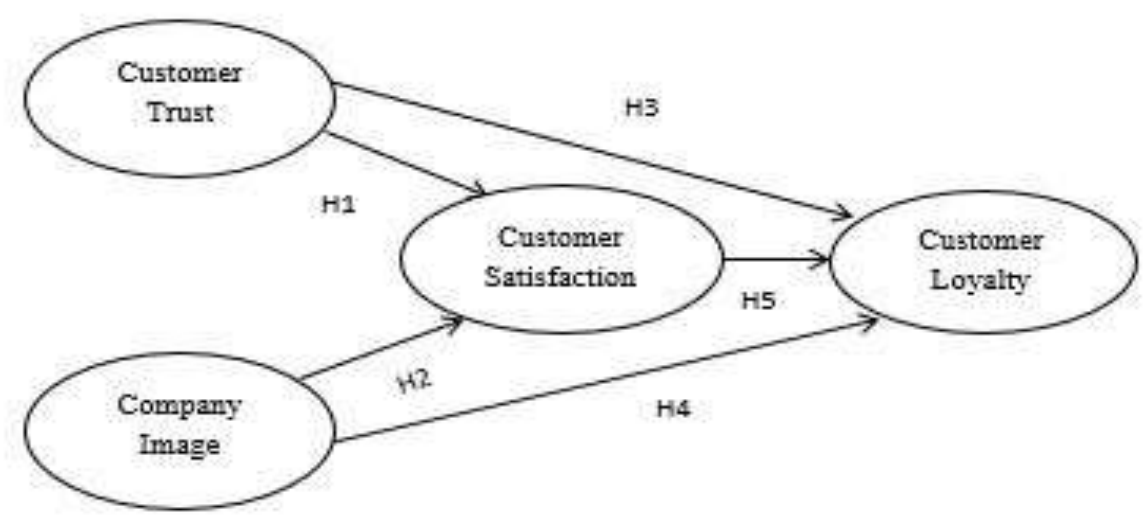

Based on the development of the hypothesis and the conceptual framework above, the following hypotheses can be stated:

1. Customer trust has a positive and significant effect on customer satisfaction at the Indonesian Classification Bureau

2. Company image has a positive and significant effect on customer satisfaction at the Indonesian Classification Bureau

3. Customer trust has a positive and significant effect on customer loyalty at the Indonesian Classification Bureau

4. Company image has a positive and significant effect on customer loyalty at the Indonesian Classification Bureau

5. Customer satisfaction has a positive and significant effect on customer loyalty at the Indonesian Classification Bureau

\section{Research Methods}

\section{Operational Definition and Variable Measurement}

\section{Customer Trust $\left(\mathbf{X}_{1}\right)$}

Customer trust is the result of positive who received someone based on the expectations and the expectations of the Bureau of Classification of Indonesia. So from that, theindicators are examined from variable customer trust are as follows:

1. Benevolence, namely goodwill good and the belief that consumers are protected and not be harmed by the ICC.

2. Realibility, namely the ability of BKI to meet the needs that required consumers.

3. Competence, namely the ability which is owned by the ICC in fulfilling the needs of customers with good

4. Honesty, the services that are given by the ICC in accordance with what the promised

5. Openness, namely openness to notify or provide information that is needed to the customer.

\section{Company Image $\left(\mathbf{X}_{2}\right)$}

Company Image is the whole impression in the mind of the customer due to the accumulation of feelings, ideas, attitudes and experiences with the Indonesian Classification Bureau company which is stored in one's memory which becomes a positive / negative meaning . Therefore, the indicators examined from the company image variable are as follows:

1. Dynamic, namely BKI is enthusiastic in developing the company to expand its business network

2. Cooperative, namely the ICC is expected to able to work together premises n well with customers 
International Journal of Economics, Business and Accounting Research (IJEBAR)

Peer Reviewed - International Journal

Vol-4, Issue-3, 2020 (IJEBAR)

E-ISSN: 2614-1280 P-ISSN 2622-4771

https://jurnal.stie-aas.ac.id/index.php/IJEBAR

3. Business-wise, that is related to how the ICC took the decision to the wise.

4. Character, namely BKI is able to show the character of the company without exaggerating.

5. Successful, the success of which was obtained BKI in the service that is given.

6. Withdrawn, is the tendency of BKI to pull themselves out of the conflict that arises. So the company is pleased to resolve the conflict is internal.

\section{Customer Satisfaction $\left(\mathbf{Y}_{1}\right)$}

Customer Satisfaction can be defined as a person's feeling of pleasure or disappointment with the Indonesian Classification Bureau (BKI) after he has compared the results / performance of the service thought to the expected performance or product results. Therefore, the indicators studied of the customer satisfaction variable are as follows:

1. Expectations for the quality of services provided by BKI, namely getting services as desired.

2. The loyalty of customers towards the quality of service that is given, that is always using the services of BKI.

3. Responses to the quality of service that is given, namely the customers feel happy with the service that was given BKI.

\section{Customer Loyalty $\left(\mathbf{Y}_{2}\right)$}

Customer Loyalty is a customer's commitment to the services of the Indonesian Classification Bureau, based on a very positive attitude and is reflected in consistent repeat purchases. Therefore, the indicators examined from the customer loyalty variable are as follows:

1. Customers tend to be loyal to use the services, which customers always use the services that are offered BKI.

2. Customers tend to do add on selling, which customers do use the service is repeated.

3. Customers are not sensitive to price, that customers are not concerned about the cost that it takes to service that is given.

4. Customers would do word of mouth that is positive, ie customers deliver on colleagues thing positive about the services that are given BKI.

5. Offers ideas services to companies, ie customers give feedback on the services that are given BKI.

\section{Population and Sample}

Population is the generalization which consists on an object or a subject that has the quality and characteristics of particular were determined by researchers to learn and then drawn conclusions Sugiyono (2013: 117). The population in this study were customers of the Indonesian Classification Bureau in Samarinda, which is a shipping company, amounting to 207 customers.

Sugiyono (2013: 118) reveals the sample is part of the number and characteristics of which are owned by the population of the. According Hair (2010) the number of samples of at least 5 times of the number of indicators, where the research is there are 19 indicators, the $19 \times 5=95$. So the samples were used in the research of this is as big as 95 respnden.

\section{Data Collection Techniques}

As for the type of data used in the study of this is the data quantitatively that the data in the form of numbers or the data results of scoring the questionnaire. The data used in this study are primary data and secondary data. Secondary data were taken from various literature both offline and online. Primary data is the data that is associated with indicators that obtained from respondents who fill out the questionnaire. The data in this study were collected by several methods namely as follows : 
International Journal of Economics, Business and Accounting Research (IJEBAR)

Peer Reviewed - International Journal

Vol-4, Issue-3, 2020 (IJEBAR)

E-ISSN: 2614-1280 P-ISSN 2622-4771

https://jurnal.stie-aas.ac.id/index.php/IJEBAR

a. Research library (library research) which searches the materials and theories have theories by studying, researching, reviewing and examining the literature that relates to the problem that will be investigated.

b. Observation, namely the collection of data through observation directly on the object that is observed.

c. Questionnaires, namely data collection by providing a list of questions to respondents that are closed with several alternative answer choices.

\section{Data Analysis Tools}

In this study using a Likert rating scale on a scale of 1-5, where 1 indicates Strongly disagree and 5 indicates Strongly agree. This study uses a Partial Least Square (PLS) analysis tool. Analysis of Partial Least Square (PLS) is a statistical technique of multivariate conducting multiple comparisons between the dependent variable and multiple independent variables. PLS is a statistical method based SEM variant designed for complete regression when there is a specific problem in the data, such as the sample size is small, the data is lost ( missing values) and multicollinearity. (Abdillah \& Jogiyanto, 2015: 161).

\section{Results And Discussion}

\section{Validity Test}

Based on the table below, it can be seen that the outer loading values all have values above 0.7. It is meaningful indicator otherwise meet Convergen validity and otherwise feasible or valid to be used in research.

\begin{tabular}{|c|c|c|c|}
\hline \multicolumn{4}{|c|}{ Outer Loading of Each Construct } \\
\hline Variable & Indicator & $\begin{array}{l}\text { Outer } \\
\text { Loading }\end{array}$ & $\begin{array}{l}\text { Value } \\
\text { Boundary }\end{array}$ \\
\hline \multirow{5}{*}{$\begin{array}{l}\text { Customer } \\
\text { Trust }\end{array}$} & X1.1 & 0.849 & 0.7 \\
\hline & X1.2 & 0.857 & 0.7 \\
\hline & X1.3 & 0.916 & 0.7 \\
\hline & X1.4 & 0.751 & 0.7 \\
\hline & X1.5 & 0.861 & 0.7 \\
\hline \multirow{6}{*}{$\begin{array}{l}\text { Company } \\
\text { Image }\end{array}$} & X2.1 & 0.785 & 0.7 \\
\hline & X2.2 & 0.870 & 0.7 \\
\hline & X2.3 & 0.881 & 0.7 \\
\hline & X2.4 & 0.844 & 0.7 \\
\hline & X2.5 & 0.899 & 0.7 \\
\hline & X2.6 & 0.889 & 0.7 \\
\hline \multirow{3}{*}{$\begin{array}{l}\text { Customer } \\
\text { Satisfaction }\end{array}$} & Y1.1 & 0.850 & 0.7 \\
\hline & Y1.2 & 0.789 & 0.7 \\
\hline & Y1.3 & 0.882 & 0.7 \\
\hline \multirow{5}{*}{$\begin{array}{l}\text { Customer } \\
\text { Loyalty }\end{array}$} & Y2.1 & 0.929 & 0.7 \\
\hline & Y2.2 & 0.947 & 0.7 \\
\hline & Y2.3 & 0.927 & 0.7 \\
\hline & Y2.4 & 0.931 & 0.7 \\
\hline & Y2.5 & 0.944 & 0.7 \\
\hline
\end{tabular}

Source : SmartPLS output

Measurement of the discriminant validity of the measurement model is assessed based on the cross loading value. If the cross loading value of each indicator of the relevant variable is greater than the corss loading of other variables, then the indicator is valid.

Cross Loading Value 
International Journal of Economics, Business and Accounting Research (IJEBAR)

Peer Reviewed - International Journal

Vol-4, Issue-3, 2020 (IJEBAR)

E-ISSN: 2614-1280 P-ISSN 2622-4771

https://jurnal.stie-aas.ac.id/index.php/IJEBAR

\begin{tabular}{|l|l|l|l|l|}
\hline & $\begin{array}{l}\text { Company } \\
\text { Image }\end{array}$ & $\begin{array}{l}\text { Customer } \\
\text { Loyalty }\end{array}$ & $\begin{array}{l}\text { Customer } \\
\text { Satisfaction }\end{array}$ & Customer Trust \\
\hline $\mathbf{X 1 . 1}$ & 0.677 & 0.663 & 0.640 & 0.849 \\
\hline $\mathbf{X 1 . 2}$ & 0.799 & 0.837 & 0.758 & 0.857 \\
\hline $\mathbf{X 1 . 3}$ & 0.804 & 0.796 & 0.784 & 0.916 \\
\hline $\mathbf{X 1 . 4}$ & 0.533 & 0.536 & 0.541 & 0.751 \\
\hline $\mathbf{X 1 . 5}$ & 0.750 & 0.754 & 0.727 & 0.861 \\
\hline $\mathbf{X 2 . 1}$ & 0.785 & 0.643 & 0.669 & 0.699 \\
\hline $\mathbf{X 2 . 2}$ & 0.870 & 0.795 & 0.735 & 0.745 \\
\hline $\mathbf{X 2 . 3}$ & 0.881 & 0.831 & 0.799 & 0.780 \\
\hline $\mathbf{X 2 . 4}$ & 0.844 & 0.690 & 0.731 & 0.680 \\
\hline $\mathbf{X 2 . 5}$ & 0.899 & 0.806 & 0.840 & 0.724 \\
\hline $\mathbf{X 2 . 6}$ & 0.889 & 0.841 & 0.859 & 0.773 \\
\hline Y1.1 & 0.734 & 0.714 & 0.850 & 0.658 \\
\hline Y1.2 & 0.732 & 0.636 & 0.789 & 0.599 \\
\hline Y1.3 & 0.803 & 0.801 & 0.882 & 0.801 \\
\hline Y2.1 & 0.825 & 0.929 & 0.833 & 0.818 \\
\hline Y2.2 & 0.859 & 0.947 & 0.884 & 0.812 \\
\hline Y2.3 & 0.812 & 0.927 & 0.845 & 0.796 \\
\hline Y2.4 & 0.846 & 0.931 & 0.819 & 0.805 \\
\hline Y2.5 & 0.847 & 0.944 & 0.817 & 0.782 \\
\hline
\end{tabular}

Source: Author compiled, 2020

Based on the analysis of PLS indicates that the value of cross loading indicator variable latency is large compared to the value of cross loading more the instrument of research is said to be valid diskriminan

\section{Reliability Test}

The outer model reliability test can use the PLS output seen from the Cronbach Alpha value. In general, it is stated that the criteria for the alpha coefficient are said to be reliable if alpha> 0.6. So that if according to the specified criteria, the alpha value is greater than 0.6 , it is declared reliable.

Value Cronbach Alpha

\begin{tabular}{|l|l|l|}
\hline & Cronbachs Alpha & Information \\
\hline Customer Trust & 0.902 & Reliable \\
\hline Company Image & 0.931 & Reliable \\
\hline Customer Satisfaction & 0.794 & Reliable \\
\hline Customer Loyalty & 0.964 & Reliable \\
\hline
\end{tabular}

Source: Primary data processed,

In addition, the reliability of latent variables with reflective indicators is evaluated based on the results of composite reliability. Variable latent said reliable if it has a value of composite reliability and iindikator which measure a variable latency of the more substantial or above of 0.70 (reliability high). The following table 5.11 presents the reliability test results of all latent variables with their respective reflective indicators.

Composite Reliability

\begin{tabular}{|l|l|l|}
\hline & $\begin{array}{l}\text { Composite } \\
\text { Reliability }\end{array}$ & Information \\
\hline Customer Trust & 0.927 & Reliable \\
\hline Company Image & 0.945 & Reliable \\
\hline
\end{tabular}


International Journal of Economics, Business and Accounting Research (IJEBAR)

Peer Reviewed - International Journal

Vol-4, Issue-3, 2020 (IJEBAR)

E-ISSN: 2614-1280 P-ISSN 2622-4771

https://jurnal.stie-aas.ac.id/index.php/IJEBAR

\begin{tabular}{|l|l|l|}
\hline Customer Satisfaction & 0.879 & Reliable \\
\hline Customer Loyalty & 0.927 & Reliable \\
\hline
\end{tabular}

\section{Goodness of Fit Model Check}

Knowing the goodness-fit of the model can be seen from the R-Square value. The R-Square value can be used to explain the effect of the independent variable on the dependent variable having a substantive effect.

\begin{tabular}{|l|l|c|c|}
\hline \multicolumn{4}{|c|}{ R - Square } \\
\hline No. & Variable & R Square & R Square Adjusted \\
\hline 1. & Customer Satisfaction & 0.822 & 0.818 \\
\hline 2. & Customer Loyalty & 0.864 & 0.860 \\
\hline
\end{tabular}

Source: Author compiled

\section{Hypothesis Test Results \\ Path Coefficients}

\begin{tabular}{|l|l|l|l|l|l|}
\hline & $\begin{array}{l}\text { Original } \\
\text { Sample }\end{array}$ & $\begin{array}{l}\text { Sample } \\
\text { Mean }\end{array}$ & $\begin{array}{l}\text { Standard } \\
\text { Deviation }\end{array}$ & $\begin{array}{l}\text { T- } \\
\text { Statistics }\end{array}$ & P Values \\
\hline $\begin{array}{l}\text { Company Image } \rightarrow \\
\text { Customer Loyalty }\end{array}$ & 0.306 & 0.293 & 0.094 & 3,269 & 0.001 \\
\hline $\begin{array}{l}\text { Company Image } \rightarrow \\
\text { Customer } \\
\text { Satisfaction }\end{array}$ & 0.724 & 0.721 & 0.085 & 8,539 & 0,000 \\
\hline $\begin{array}{l}\text { Customer } \\
\text { Satisfaction } \\
\text { Customer Loyalty }\end{array}$ & 0.405 & 0.415 & 0.099 & 4,070 & 0,000 \\
\hline $\begin{array}{l}\text { Customer Trust } \\
\text { Customer Loyalty }\end{array}$ & 0.264 & 0.263 & 0.082 & 3,225 & 0.001 \\
\hline $\begin{array}{l}\text { Customer Trust } \rightarrow \\
\text { Customer } \\
\text { Satisfaction }\end{array}$ & 0.206 & 0.206 & 0.088 & 2,331 & 0.020 \\
\hline
\end{tabular}

Source: Primary data processed

H1: Stating that Customer Trust has a positive and significant effect on Customer Satisfaction. The results of testing the hypothesis of the value of T-statistics are 2,331> 1,96, which means that the hypothesis which states that Customer Trust has a positive and significant effect on Customer Satisfaction is proven true or $\mathrm{H} 1$ is accepted.

H2: Stating that Company Image has a positive and significant effect on Customer Satisfaction. Based on the results of hypothesis testing, it is known that Company Image has a positive and significant effect on Customer Satisfaction with a T-statistics value of 8,539 $<1.96$. So that the results of this study are in accordance with the third hypothesis which states that Company Image has a positive and significant effect on Customer Satisfaction. Hypothesis 2 is accepted.

H3. Stating that Customer Trust has a positive and significant effect on Customer Loyalty. Based on the results of hypothesis testing, it is known that Customer Trust has a positive and significant effect on Customer Loyalty with a T-statistics value of 3,225>1.96. So that the results of this study are in accordance with the second hypothesis which states that Customer Trust has a positive and significant effect on Customer Loyalty or hypothesis 3 is accepted.

H4: Stating that Company Image has a positive and significant effect on Customer Loyalty. Based on the results of hypothesis testing, it is known that Company Image has a 
International Journal of Economics, Business and Accounting Research (IJEBAR)

Peer Reviewed - International Journal

Vol-4, Issue-3, 2020 (IJEBAR)

E-ISSN: 2614-1280 P-ISSN 2622-4771

https://jurnal.stie-aas.ac.id/index.php/IJEBAR

positive and significant effect on Customer Loyalty with a T-statistics value of 3.269> 1.96. So that the results of this study are in accordance with the fourth hypothesis which states that Company Image has a significant effect on Customer Loyalty proven true or hypothesis 4 is accepted.

H5: Stating that Customer Satisfaction has a positive and significant effect on Customer Loyalty. Based on the results of hypothesis testing, it is known that Customer Satisfaction has a positive and significant effect on Customer Loyalty with a T-statistics value of 4.070>1.96. So that the results of this study are in accordance with the fifth hypothesis which states that Customer Satisfaction has a significant effect on Customer Loyalty proven true or hypothesis 5 is accepted.

\section{Discussion}

\section{The Influence of Customer Trust on Customer Satisfaction}

Based on the results of the analysis and hypothesis testing with a t-statistic value greater than the t-table, the customer trust variable has a positive and significant effect on customer satisfaction. The results of the analysis illustrate that the existing customer trust variables consisting of indicators of benevolence, reliability, competence, honesty, and openess are currently able to create an influence on customer satisfaction.

Customer trust is a positive result received by a person based on the expectations and expectations of a product or service provided by a company. The test results in this study indicate that the hypothesis which states that customer trust has a positive and significant effect on customer satisfaction can be accepted. This shows that the indicators used in this study are able to encourage customer satisfaction. This result means that customers of PT Biro Klasifikasi Indonesia (BKI) feel that the expectations and expectations they want can be met by PT Biro Klasifikasi Indonesia so that consumers feel confident in the services provided by the company which then creates a sense of satisfaction for consumers.

\section{Effect of Company Image on Customer Satisfaction}

Company image has a positive influence on customer satisfaction, meaning that the better the company image in the eyes of customers, the better or higher the customer satisfaction. With a T-statistics value of 8,539> 1.96, which means that the company image has a significant relationship to customer satisfaction. PT Biro Klasifikasi Indonesia has been able to create a good company image for its consumers. Consumers feel PT BKI has a good image in the eyes of consumers. This result means the efforts made by PT BKI to create a good image with successes in serving the classification of ships and policies that make PT BKI have an image that is considered good by consumers.

\section{The Influence of Customer Trust on Customer Loyalty}

Based on the results of hypothesis testing, it is known that customer trust has a positive and significant effect on customer loyalty. So that the results of this study are in accordance with the third hypothesis which states that customer trust has a significant effect on customer loyalty. This means that customer trust has been able to create customer loyalty to the services provided by PT BKI. It means that what has been done by PT BKI to create consumer confidence in the company is successful, its successes, and the ability to be relied upon in serving the classification of ships and the policies implemented by the company such as information disclosure to consumers, as well as the good intentions shown by PT BKI in serving consumers make consumers trust PT BKI so that they show loyalty to the company PT BKI. 
International Journal of Economics, Business and Accounting Research (IJEBAR)

Peer Reviewed - International Journal

Vol-4, Issue-3, 2020 (IJEBAR)

E-ISSN: 2614-1280 P-ISSN 2622-4771

https://jurnal.stie-aas.ac.id/index.php/IJEBAR

\section{The Effect of Company Image on Customer Loyalty}

Based on the results of hypothesis testing, it is known that company image has a positive and significant effect on customer loyalty. This means that the better the company image has a positive and significant effect, the higher customer loyalty will be. Based on the results of hypothesis testing, it is known that company image has a positive and significant effect on customer loyalty with a T-Statistics value of 3.269> 1.96. So that this research is in accordance with the fourth hypothesis which states that company image has a significant effect on customer loyalty. This result means that PT BKI can create a good image in the eyes of consumers so as to increase consumer loyalty to PT BKI.

\section{The Influence of Customer Satisfaction on Customer Loyalty}

Based on the results of hypothesis testing, it is known that customer satisfaction has a positive and significant effect on customer loyalty. This means that the higher the level of customer satisfaction has a positive and significant effect, the higher the level of customer loyalty. Based on the results of hypothesis testing, it is known that customer satisfaction has a positive and significant effect on customer loyalty with a T-Statistics value of 4.070>1.96. So that the results of this study are in accordance with the fifth hypothesis which states that customer satisfaction has a significant effect on customer loyalty, proven true or hypothesis 5 is accepted. This result means that the customer satisfaction created by PT BKI is able to satisfy consumers as a ship classification service provider so that this will increase PT BKI's customer customer loyalty.

\section{Conclusion}

1. Based on the results of hypothesis testing, the value of $t$-statistic is greater than $t$ table, which means that the hypothesis that Customer Trust has a positive and significant effect on Customer Satisfaction is proven true or hypothesis 1 is accepted .

2. Based on the results of hypothesis testing, it is known that Company Image has a positive and significant effect on Customer Satisfaction with a statistical $t$ value greater than $t$ table. So that the results of the study indicate that hypothesis 2 is accepted

3. Based on the results of hypothesis testing, it is known that Customer Trust has a positive and significant effect on Customer Loyalty with a statistical $t$ value greater than $t$ table. So that the results of this study are in accordance with the third hypothesis which states that Customer Trust has a positive and significant effect on Customer Loyalty or hypothesis 3 is accepted.

4. Based on the results of hypothesis testing, it is known that Company Image has a positive and significant effect on Customer Loyalty with a statistical $t$ value greater than $t$ table. So that the results of this study are in accordance with the fourth hypothesis which states that Company Image has a significant effect on Customer Loyalty proven true or hypothesis 4 is accepted.

5. Based on the results of hypothesis testing, it is known that Customer Satisfaction has a positive and significant effect on Customer Loyalty with a statistical t value greater than $\mathrm{t}$ table. So that the results of this study are in accordance with the fifth hypothesis which states that Customer Satisfaction has a positive and significant effect on Customer Loyalty proven true or hypothesis 5 is accepted.

\section{Suggestion}

1. It is recommended that the Indonesian Classification Bureau maintains indicators of Customer Trust that have a positive and significant impact on Customer Satisfaction. 
International Journal of Economics, Business and Accounting Research (IJEBAR)

Peer Reviewed - International Journal

Vol-4, Issue-3, 2020 (IJEBAR)

E-ISSN: 2614-1280 P-ISSN 2622-4771

https://jurnal.stie-aas.ac.id/index.php/IJEBAR

2. It is recommended to the Indonesian Classification Bureau to maintain Company Image forming indicators that have a positive and significant impact on Customer Satisfaction.

3. It is recommended that the Indonesian Classification Bureau maintains indicators of Customer Trust that have a positive and significant impact on Customer Loyalty.

4. It is suggested to the Indonesian Classification Bureau to maintain Company Image forming indicators that have a positive and significant influence on Customer Loyalty.

5. It is suggested to the Indonesian Classification Bureau to maintain the indicators of Customer Satisfaction that have a positive and significant impact on Customer Loyalty.

6. For the company to be able to maintain the variables that have been assessed well according to the perceptions of its customers

7. For further researchers, they can conduct research to see the direct and indirect relationship between variable $\mathrm{X}$ and variable $\mathrm{Y}$

\section{References}

Abd-el-salam, EM, \& Shawky, AY (2013). The impact of corporate image and reputation on service quality, customer satisfaction and customer loyalty: testing the mediating role. Case analysis in an international service company, 3 (2), 177-196.

Ashraf, MA, \& Niazi, AA (2017). Impact of Brand Image, Service Quality and Trust on Customer Loyalty, Moderating Effect of Perceived Price Fairness and the Mediating Effect of Customer Satisfaction: Case Study on Telecommunication Sector of Pakistan.

Bravo, R., Montaner, T., \& Pina, JM (2009). The role of bank image for customers versus noncustomers. International Journal of Bank Marketing . https://doi.org/10.1108/02652320910968377

Doma, SSB. (2013). Relationship Quality as Predictor of B2B Customer Loyalty, 11 .

Ghozali, I., \& Latan, H. (2014). Partial Least Square: Concepts, Methods \& Applications Using the Warppls 4.0 Program (2nd ed.). Undip.

Gounaris, SP (2003). Trust and commitment influences on customer retention: Insights from business-to-business services. Journal of Business Research, 58 (2 SPEC.ISS.), 126140. https://doi.org/10.1016/S0148-2963(03)00122-X

Griffin, R. (2010). Customer Loyalty: Growing and Maintaining Customer Loyalty . MIT Press Books . https://doi.org/10.1109/IEMDC.2003.1210404

Hair. (2010). Multivariate Data Analysis . United States: Pearson.

Halliburton, C., \& Poenaru, A. (2010). The Role of Trust in Consumer Relationships. ECSP Europe.

Hawkins, DI, Kollat, DT, Best, RJ, Bitta, AJ Della, Schiffman, LG, Scott, CA,... Coney, KA (2008). Consumer Behavior Consumer Behavior: Implications for Marketing Strategy Consumer Behavior: Concepts and Applications Consumer Behavior and the Practice of Marketing Consumer Behavior: Basic Findings and Management Implications. Journal of Marketing . https://doi.org/10.2307/1251730

Hidayat, R., \& Akhmad, S. (2015). Effects of Service Quality, Customer Trust and Customer Religious Commitment on Customer Satisfaction and Loyalty of Banks in East Java, $151-164$.

Jogiyanto. (2011). BUSINESS RESEARCH METHOLOGY. (BPFE-YOGYAKARTA, Ed.) (4th ed.). BPFE-YOGYAKARTA.

Jones, TO, \& Sasser Jr., WE (2009). Why Satisfied Cutomers Defect. Harvard BusinessReview . https://doi.org/10.1061/(ASCE)0742-597X(1996)12:6(11.2) 
International Journal of Economics, Business and Accounting Research (IJEBAR)

Peer Reviewed - International Journal

Vol-4, Issue-3, 2020 (IJEBAR)

E-ISSN: 2614-1280 P-ISSN 2622-4771

https://jurnal.stie-aas.ac.id/index.php/IJEBAR

Khan, I. (2012). Impact of Customers Satisfaction And Customers Retention on Customer Loyalty, 1 (2).

Kotler, P., \& Keller, kevin lane. (2009). MARKETING MANAGEMENT . (J. Purba, Ed.) (12th ed.). PT.indeks.

Kotler, P., \& Keller, KL (2005). Marketing Management Volume 1 . Jakarta: Index .

Kuo, CW, \& Tang, ML (2013). Relationships Among Service Quality, Corporate Image, Customer Satisfaction, and Behavioral Intention For The Elderly in High Speed Rail Services, (October 2011), 512-525. https://doi.org/10.1002/atr

Mosavi, SA, \& Ghaedi, M. (2012). A Survey on The Relationship Between Trusts, Customer Loyalty, Commitment and Repurchase Intention, 6 (36), 10089 10098. https://doi.org/10.5897/AJBM11.2741

Nguyen, N., \& Leblanc, G. (2002). Corporate image and corporate reputation in customers' retention decisions in services. Journal of Retailing and Consumer Services . https://doi.org/10.1016/s0969-6989(00)00029-1

Risdianto, GE \& Japarianto, E. (2014). The Influence of Customer Satisfaction and Switching Barriers on Customer Loyalty by Using Customer Trust Variables as Moderating Variables at Petra Togamas Bookstore, Surabaya. Journal of Marketing Management, 10.

Ross, B., Canning, L., \& McDowell, R. (2004). Business to Business Marketing: A step-bystep Guide. Prentice Hall. Pearson Education Limited .

Sari, N. (2018). Service Quality, Company Image, Trust and its Influence on Customers' Satisfaction and Loyalty at Bank Shariah Mandiri (BSM) Meulaboh Branch Office, 6 (2).

Sarwar, MZ, Abbasi, KS, \& Pervaiz, S. (2012). The Effect of Customer Trust on Customer Loyalty and Customer Retention: A Moderating Role of Cause Related Marketing, 12 (6).

Semuel, H., \& Wijaya, E. (2007). Corporate Social Responsibility, Purchase Intention and Corporate Image at Restaurants in Surabaya from a Customer Perspective. Journal of Marketing Management, 3 (1), 35-54.

Setiawan, H., \& Sayuti, AJ (2017). Effects of Service Quality, Customer Trust and Corporate Image on Customer Satisfaction and Loyalty: An Assessment of Travel Agencies Customer in South Sumatra Indonesia. IOSR Journal of Business and Management , 19 (05), 31-40. https://doi.org/10.9790/487x-1905033140

Setyono, L. (2015). The Effect of Islamic Marketing and Corporate Image on Customer Satisfaction and Customer Loyalty (Study on Customers of PT Bank Muamalat Indonesia Malang Branch Office), 27 (1).

Sheng, T., \& Liu, C. (2010). An empirical study on the effect of e-service quality on online customer satisfaction and loyalty. Nankai Business Review International . https://doi.org/10.1108/20408741011069205

Sudjana. (2009). Statistics . Bandung: Tarsito.

Tjiptono, F. (2014). Marketing of Services - Principles, Applications, and Research In 1 .

Tjiptono, F., \& Chandra, G. (2005). Service Quality Management. Yogyakarta. ANDI . https://doi.org/10.12691/jbms-4-4-1

Tschannen-Moran, M. (2001). Collaboration and the need fortrust. Journal of Educational Administration . https://doi.org/10.1108/EUM0000000005493

Zeithaml, VA, Bitner, MJ, \& Gremler, DD (2003). Services Marketing Strategy. In Wiley International Encyclopedia of Marketing . https://doi.org/10.1002/9781444316568.wiem01055

Zimmerman, A., \& Blythe, J. (2013). Business to Business Marketing Management (2nd Edition). 711 Third Avenue, New York, NY 10017 Routledge: Routledge . 